\title{
A Critical Analysis of Startup Business in Indonesia by Means of Mato-Based Profit Sharing Accounting
}

\author{
Hanif* \\ Institut Bisnis dan Informatika Kwik Kian Gie, Jl. Yos Sudarso Kav.87, Sunter, 14350, Jakarta
}

\begin{abstract}
Objective - This research aims to analyze and deconstruct digital-based startup business practice and offer a new concept of sharing economy. The online transportation companies operated in Indonesia, have been selected as the subject of the research.

Methodology/Technique - A critical paradigm referring to mato-based profit sharing accounting was used as a method of the research. Data was collected from online transportation companies' websites as well as either news or media article published on mass media.

Findings - On the other side, it has not completely been in line with the practice of profit sharing economy concept which has long been the ideal of the constitutional ideology of Indonesia. Thus, in the final section of this research, a new concept of sharing economy, which is relatively in line with the constitutional ideology of Indonesia is proposed for practice in startup companies.
\end{abstract}

Novelty - The study proposes new concept of sharing economy for startup business.

Type of Paper: Review

Keywords: Incentive; Startup Business; Sharing Economy; Profit-Sharing; Mato System; Constitutional Ideology.

JEL Classification: M13, M21, M41.

\section{Introduction}

The term "sharing economy" appears to describe innovative business phenomena by utilizing information technology that gives rise to a number of applications used to manage a business through the internet network. A business breakthrough applying information technology as used for operating the online transportation, hotel industry can be applied by a company owning the application to match two parties in need. The party having private idle assets (motorbike, car, house, apartment) is to be matched with other parties: consumers of transportation and accommodation services. i.e. cars, motorbikes, delivery, hotel, homestay and the like.

This kind of business is managed in a collaborative system by utilizing idle personal resources. It is possible to operate since it is supported with internet-based application that allows public preference for more inexpensive rate and easier access to place an order. The inexpensive rate is the result of cost efficiency, either for investment or operation because the advancement of digital technology can cut off a business chain to be

\footnotetext{
* Paper Info: Received: October 25, 2016

Accepted: April 12, 2017

* Corresponding author:

E-mail: hanif.ismail@kwikkiangie.ac.id

Affiliation: Accounting Department, Insitutut Bisnis dan Informatika Kwik Kian Gie, Indonesia
} 
more simplified. This condition may lead to a fluctuation and polemic between existing businessmen applying conventional system and startup businessmen applying digital system. The fluctuation happens when the existing businessmen having placed a big investment feel threatened due to the price competition offered by the startup businessmen who usually win the pricing (Kompas 29th March 2016).

Beyond the controversy of emerging startup business, it cannot be avoided that a positive side and stunning philosophy of this business system do exist. Kasali (2016) revealed that startup business on sharing economy is a sociol-economic reality driven by young generation living with digital mindset and having shifted their perspective of sociol-economy reality from owning economy into the sharing economy instead. Further, Kasali (2016) explained that regarding former viewpoint, the former businessmen relied on owning economy when running and building their business empire. This had allowed a main pillar in capitalist system to exist when a desire to pile up private assets increasingly grew uncontrollably. Consequently, a number of idle assets would remain whereas other people have been found to live in scarcity of resources in other parts of the world. In contrast with the aforementioned, the young generation with digital technology basis is striving to collect public resources with an abundant asset (excessive capacity) for a trade with other parties in need. This has to be done in order to utilize some idle capacities existing in such abundance

However, there has been pros and cons in terms of startup business in Indonesia. First, a startup business practice has received a harsh protest from conventional business managers who can hardly win the market due to losing the competition in "service rate". A startup company may not need big investment and can conversely, cut off the business chain for efficiency. Second, pros and cons emerge due to the use of sharing economy concept in this startup company. Sharing economy terminology is meant to be a word referring to a more humane socialist economic system, particularly given on the stressed word "sharing". In fact, the so-called sharing economy practice implemented in this modern era has run differently, in which only particular people, the owners as well as managers of application, earn the most in the business. In addition, the effect of digital application-based sharing economy has indeed shortened the economy chain so that it significantly reduces job opportunities (Prasetyantoko, 2016). In result, it leads to a new form of capitalist system; therefore, it cannot precisely refer to socialist economy (Priyono, 2016).

This research belongs to the reality of accountancy, particularly of management accounting which is a critical analysis of a new creation that combines digital technology advancement and social process in the business strategy setting and management control that aim to improve welfare and profit for all parties involved in the company. We believe that the science of accountancy is a social instead of natural science. Therefore, theories in social sciences can be employed in this research in accountancy as if it functioned as a knife to explore the analysis (Kamayanti 2016; Triyuwono 2012). A critical paradigm was used in this research to deconstruct the sharing economy concept carried by startup business. Burrel and Morgan (1997) revealed that a critical paradigm is based on a belief that the community is under the alliance, and colonization by an ideology and demands for a radical change (Kamayanti 2016). What about the startup business online transportation in Indonesia? Can this sort of sharing economy, business colonize the community with digital technology ideology? This research is conducted to give answers to those kinds of questions. Specifically, the research questions are: how is the construction of ideology in startup business on the sharing economy applied nowadays, and how is the ideal concept of this sharing economy applied to be in line with the constitutional ideology of Indonesia?

\section{Literature Review}

The term sharing economy emphasizes on the word "sharing". Kasali (2016) noted that the sharing economy is a concept in economy initiated by the young who are born and live with digital information technology mindset. With the sophistication of current digital technology, there appear new ideas to solve social and economic problems in society. The enormous impact of digital technology can turn an old capitalist-based business concept oriented to owning a company into its antithesis: sharing economy that gives emphasis on the word "sharing". The order of business economy is steadily changes and will keep on changing. One 
fundamental change is that the business activity does not only rely on physical capital, but also ideas to bring the parties having excessive resources together with other parties in need, so that in aggregation if the system is accepted by large societies- the world will run an efficient business practice in the long term. This will contribute to saving the world from abundant capacity due to excessive resources from the capitalist economic system. Unfortunately, the system has opened a big space for unlimited private possession that results in efficiency eventually. Sharing economy system is likely to carry out and run because the presence of digital information technology has created a number of application systems driving to the emergence of a startup business.

Philosophy of startup business has drawn businessmen's attention not to mention the big companies which are trying to adopt the culture of this kind of business. An effort to improve a business process, which a corporate used to manage by itself, has to deal with an alternative to having another more specialist company manage it in a given field for effectiveness and efficiency to gain customer satisfaction. A Korean company, Samsung has declared to adopt the culture of startup business on a sharing economy concept by changing the communication between superordinate-subordinate, eliminating grading hierarchy, making a flexible working hours, minimizing unnecessary meetings, and encouraging workers to have a chat with their family.

The presence of digital technology-based startup business cannot be avoided as suggested by Kasali (2016) that the businessmen of conventional transportation must adapt to the development of this business trend due to the existence of digital technology advancement. Yet, is it true that the concept of sharing economy has been really emphasized on the word "sharing" in contrast with owning, or is this concept merely another form the businessmen take into action to gain the most profit as to the interest of particular people?

The emphasis of the word "sharing" as a concept of sharing economy is declared in the concept of economy in Indonesia on the basis of constitutional ideology. The 1945 Constitution of the Republic of Indonesia Article 33 paragraph 1 declares that the economy shall be organized as a common endeavour based upon the principles of the family system. The article obviously urges the economic system of Indonesia described in a business practice to refer to the core values of "togetherness" and "family system which in fact belong to the concept of sharing economy. This is in accordance with Pancasila, the Indonesian state philosophy, of which principles prefer an economic system based upon social justice and uphold business ethical attitudes in compliance with the moral values of divinity.

The term sharing economy has long existed in the socio-culture and economy of Indonesia. One form of it is a profit sharing system. Hanif, Ludigdo, Rahman, \& Baridwan, (2015) noted that the business practice in Padang Restaurant has been accorded to mato profit sharing system of which management is based on local wisdom. i.e. mutual aid (gotong-royong), justice, togetherness, and the values of equality. These values are relatively in line with the economic ideology of Indonesia complying with Pancasila and the 1945 Constitution of the Republic of Indonesia.

The business practice not to mention the economic system conducted in Indonesia (by private or state) seem to have been far beyond the ideal concept of economy on the basis of constitutional ideology. Baswir (2002) strictly emphasized that there has been a constitutional violation in running the economic system in Indonesia for the period of new era government to present condition because of the practice of capitalism instead of constitutional ideology-based economic system.

\subsection{Mato-based Profit Sharing Accounting Applied in Padang Restaurant}

\subsubsection{Introduction to Mato System}

In this research, mato is meant to be loaded. Hanif, Ludigdo, Rahman, and Baridwan, (2015) noted that mato system is used in a profit sharing-based business. It allows each stakeholder in a company to be given a load (Mato) that represents authority, responsibility, and right he or she owns in the company. The load (Mato) is determined by a score, the higher score it is proportionally given, the bigger authority, responsibility and the right one has in a company. This system does not allow employees in the company to have a salary; instead 
they will earn from the profit sharing calculated within a particular period of time, and so will the investor and manager (brand owner). The "profit" is periodically shared under profit sharing scheme that is 50 percent for all employees and the other 50 percent for two parties (investor and brand owner). It can be said that the portion of (Mato) between the two parties under this calculation is equal; 50:50. This system allows mato profit sharing scheme to apply at the employees' level. What they deserve to earn is determined by giving the (Mato) to the employees from the lowest to the highest level under the organizational structure. (Mato) is distributed accurately, carefully and measurably in such a way that all employees can understand and accept why each will receive differently. The high or low (Mato) the employees receives relies on expertise, position, responsibility in accordance with the structure, loyalty, working period, and working attitude so that each of them might earn different amounts due to different (Mato) gained (Hanif, Ludigdo, Rahman, \& Baridwan, 2015; Hanif 2016).

\subsubsection{Local Wisdom Values of Mato-based Profit Sharing Accounting}

The idea of mato system is to position man at work to be relatively equal. The equality refers to the absence of highly significant difference among investor, brand owner and employees. The employees may also feel relatively "high" owing to the absence of "wage and salary" system. The profit sharing system is indeed in place of it. Therefore, they will sense that what they earn will be the impact of their creation, creativity, and hard work. The employees have to risk for having no fixed monthly "wage and salary" so that the earning they strive for reflects their struggle for the risk.

\section{Methodology}

A critical paradigm was employed in this research to understand the social reality of sharing economybased startup business. A critical analysis was initiated by the researcher's deep understanding of the astonishing social reality of such startup business online transportation in Indonesia that upholds sharing economy as anti-thesis of the capitalist economy system applying owning economy, but is this reality true? It requires further steps to investigate.

An observation of the real practice of startup business is required to conduct to justify whether or not the sharing economy is merely "all fur coat and no knickers" of the capitalist. Next, identification is performed to "pluck" the fur off "the coat". The fur will then be injected with the core values and essence of a sharing economy into which the startup business is embedded.

Data collection and analysis were conducted under the following stages. First, it is to dig up information about the presence of startup business in Indonesia like online transportation. The collected data includes: information derived from respective website, mass media, relevant articles, and expert's quotes on mass media on the existing business. Second, it is to analyze a text revealed in each resource of information. This aims to figure out the essence of social reality occurring in the business process of startup companies along with its embedded values. Third, it is to identify dominant capitalist values attached to a sharing economy-based startup business and it is followed by refining (emancipatory) the concept of sharing economy with the perspective of Mato-based profit sharing account. The perspective of Mato-based profit sharing accounting has been a knife to explore the social reality of sharing economy-based startup business because this concept is formulated from a business practice which has relatively adjacent values to constitutional ideology of Indonsia (Hanif, Ludigdo, Rahman, \& Baridwan, 2013a; 2015; Naim, Paragon, Asril, \& Rasyid, 1987).

\section{Results}

\subsection{Tracing the Business Process of Sharing Economy}

The sharing economy concept - growing, naturally as previously explained - is increasingly developing along with the young's creativity living in a digital technology era. Numerous applications have been created 
to ease people in need. The applications can be easily accessed. They are very simple in operation; all communication takes place by means of the application. The application owners of the online transportation invite people who have "excessive" assets, especially private vehicle to join them for making more income by "commercializing" their idle vehicles and registering themselves for being the "driver" ready to be commercialized and empowered by meeting the administrative requirement in an easy way. Next, the users (customers) can easily download the application through the internet and can directly use it to order the transportation service. The order is communicated by means of the same application and received complete with information about the identity of the vehicle and the driver, driver's current position, and rate to destination. Having used the service, customers can give feedback over the driver's service and vehicle facility. The latter will be the medium used by the company as a control mechanism to monitor the quality of the service. How easy the process of this startup business is mainly due to the masterpiece of innovation in digitalbased application. There seems to have been day-to-day new innovation in digital world that eases the business process more involving and empowering public and the workforce. This concept can be said as the sharing economy, which Kasali (2016) considered contradicting the owning economy.

\subsection{Analysis of Pros and Cons of the Existing Startup Business}

There has always been "uproar" over a new and "extraordinary" thing in any business practice in the world. It is worsened when the new business threatens the existing business run by "old" management. The phenomenon of digital-based business like online transportation creates a business practice in transportation and distribution once it was hard to believe. However, the creativity of the young generation living in digital mindset has brought up a good side to make dreams come true. The owner of excessive and idle resources by means of this application - can be made productive for transportation business as the owner can meet the parties in need with the help of the application regardless of the broker. The rate of the service is relatively very low since this business makes use of idle capacity of private assets. Therefore, businessmen using such application build their transportation business with the absence of investment (fixed cost) such as cars and motorbikes; instead, they can make use of their private idle assets to minimize the rate. Aided by this application, the customers also have an easy access to the offered transportation service so that they take advantage of it. The public feels that their needs have been well fulfilled. In contrast, the existence of this type of business, due to its less expensive rate, threatens conventional transportation business and arouses pros and cons.

Kasali (2016) is one observer in management who supports the startup business. He further concludes that this business upheld by the young and based upon digital technology can no longer be stopped, but it will sprint ahead in line with the character of information technology which develops and changes very fast and dynamic. Kasali (2016) also reveals that startup business on the sharing economy concept is the answer to and way out of a number of excess resulted from owning economy which has been the "blood child" of capitalist economy. The presence of the online transportation opens a wider opportunity for the community and offers a solution to unemployment. In result, the economy will run better because it has a multiplier effect; national efficiency. The online transportation companies are present in the middle of huge chaos resulting from job termination taking place in some business sectors in Indonesia. The unemployed may have an opportunity to do some activities if they are willing to.

The presence of this transportation business as one breakthrough using online transportation applications should be given a thumb up. Their best achievement is to find a solution to chaotic transportation system in big cities. They give the opportunity to many people, especially in informal jobs, increase community welfare by utilizing idle capacity over private assets with low rate. In terms of job opportunity, they are successfully excellent to help job seekers without complicated administrative requirement in spite of strict control management. Every customer is given the opportunity to give feedback, comment, complaint, over the service the driver has given. If there is something to lose, the driver will be terminated. The writer as the user himself also enjoys this friendly use system. There is no need to wait any longer for an order to meet. Shortly after 
placing the order, it will be responded in the second by the application. Therefore, this digital-based transportation service has becoming favorite of Jakarta's people.

Prasetyantoko (2016) suggested that digital-based startup business is unbelievably hard to stop developing despite it being part of a capitalist-based business practice which in terms of macro economy has caused the loss of the country. It cuts the business chain and minimizes job opportunity. Prasetyantoko (2016) noted that startup business will eventually widen the gap of earnings between those who have the power of digital technology and do not whose profit is capitalized the most by the very few application owners. On the other side, startup business offers uncertainty and no protection for the employees and customers. Furthermore, the social, humanistic values embedded in the company's vision and mission are not completely carried out. This business will earn the same amount as conventional business that is to maximize profit for a small group of people, the inspirations and application owners. The business in terms of employment is more profitable for those who are trying to earn more income. However, for those who make it as a full time job, it will not be that secure and equal to stay with this occupation. The employees are not under a work contract and health protection. Their employment fundamental rights are not met. The profit sharing applied in this startup business online transportation is based upon revenue sharing with a ratio of $15-20 \%$ of the applicable companies, and $80 \%-85 \%$ of the driver and vehicle owner.

\section{Discussion}

The idea of mato-based profit sharing accounting has been the knife to explore the analysis of the social reality of sharing economy-based startup business as this concept is formulated from a business practice of Padang restaurant which relatively has values in line with the constitutional ideology of Indonesia (Hanif, Ludigdo, Rahman, \& Baridwan, 2013a; 2015; see also Naim, Paragon, Asril, \& Rasyid, 1987). The construction of profit sharing accounting in startup business will be refined (reconstructed) with the concept of MAVAS (Mato Value Added Statement)-based sharing economy as illustrated in Figure 1.

Profit-sharing or revenue sharing is one option in profit sharing method, but both approaches are valid as long as they involve parties in prior sharing agreement over the profit sharing scheme and its distribution. No one feels cheated in the negotiation and the distribution. If it applies Mato system that grows from local wisdom of the community (Hanif, Ludigdo, Rahman, \& Baridwan, 2013a; 2013b; Hanif, Ludigdo, Rahman, \& Baridwan, 2015; Hanif 2016), the profit sharing concept of online transportation companies can also be developed into Mato-based revenue sharing. The latter is a new concept the writer offers to be implemented in online transportation. Its surely not only modifies the former concept by including a mato system in profit sharing scheme of online transportation, but also has the values beyond injected in the system as they are one package attached to each other. The values cover egalitarianism, openness, fairness, democracy, equality and appreciation toward member achievement. Having these values, this will complete the implementation of sharing economy. Regarding the context of online transportation companies, the "emotional bond" not only takes place through communication behind the least "human touch" but also combines with a cultural approach in the attempt to inject the values. The founder and management board of application companies have to be "down to earth" to create an informal organizational structure at the level of the "freelancer", such as establishing "association of freelancer" or whatever it takes, according to geographical area to provide a means for sharing and discussion for the success of the job and the company. Furthermore, one representative of the association should be appointed as managing board to communicate the aspiration of the "freelancer". Thus, the "freelancer" and application owners have stronger "emotional bond" which becomes the social capital of the company to advance. 


\section{Resource}

Gross Income

X $100 \%$

$$
==\quad===
$$

Distribution (profit-sharing):

$\begin{array}{ccc}\text { Partner "freelancer" (80\%) } & \text { X } & 80 \% \\ \text { Application Owner (20\%) } & \text { X } & 20 \% \\ & ==== \\ 100 \% & & \end{array}$

Resource

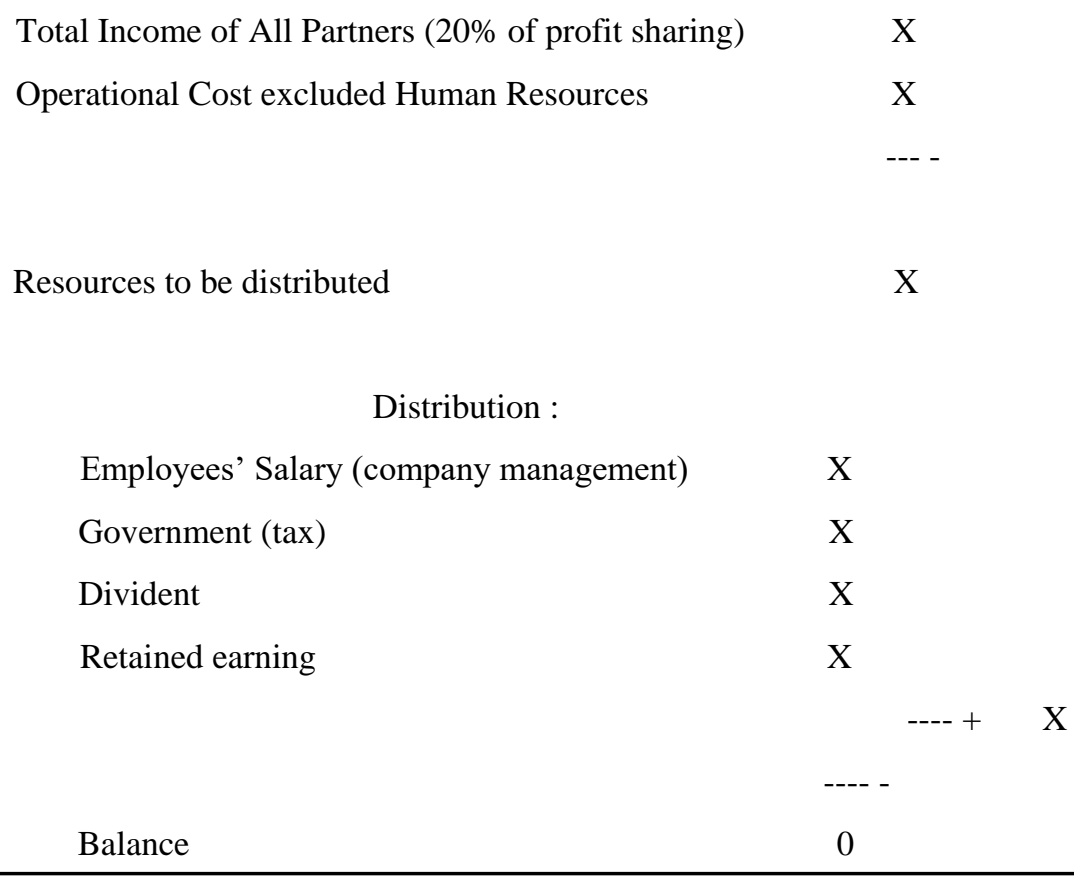

Figure 1. Formation of Profit Sharing-Based Startup Business

Source: Adopted from MAVAS model of Hanif, Ludigdo, Rahman, \& Baridwan (2015) modified by Hanif (2016)

The implementation of Mato (point) distribution to all stakeholders, including the "freelancer" should consider achievement, loyalty, and authority that each party has. Figure 2 describes the profit sharing pattern between the "freelancer" and application owners in online transportation companies in which it ranges from $15 \%-20 \%$ compared to $85 \%-80 \%$ on the basis of gross revenue instead of profit. This actually shows a comparison of mato owned by two parties. Yet, the modification remains open and fair according to the development of the organization.

\section{Conclusion}

Online transportation companies as startup companies upholding the sharing economy concept and impressed by the humanistic socialist system are indeed not in light of its ideal in practice, though this new model is able to break all limitations occurring in conventional business. Appreciation should also be given to those who join the business. However, the perfection on the concept is to be made necessary to conduct. It has been offered by the writer as a new concept of a sharing economy based upon revenue sharing with mato system injected from mato-based profit sharing accounts of Padang Restaurant. 


\section{References}

Baswir, R. (2012). Demokrasi Terjajah, Kompas Newspaper.

Burrell, G. d. M., Gareth. (1997). Sociological Paradigms and Organizational Analysis. England: Ashgate Publishing Limited.

Hanif. (2015a). Pencarian Makna Dibalik Akuntansi Kewirausahaan Berbasis Kearifan Lokal [Search Meaning Behind Local Wisdom-Based Entrepreneurship Accounting]. Jurnal Akuntansi, 4(1), 1-20.

Hanif. (2015b). Management Control System Design: An Interpretive Ethnography. Procedia - Social and Behavioral Sciences, 211, 119-126. doi: http://dx.doi.org/10.1016/j.sbspro.2015.11.018

Hanif. (2015c). Introducing Mato Based Profit-Sharing Accounting and its Synergy with Cooperative and Sharia. Procedia - Social and Behavioral Sciences, 211, 1223-1230. doi: http://dx.doi.org/10.1016/j.sbspro.2015.11.163

Hanif. (2016). Sinergi Oposisi Biner Dalam Rangka Re(Konstruksi) Akuntansi Keuangan Bagi-Hasil Sistem Mato [Synergy of Binary Opposition In Order Re (Construction) Financial Accounting Profit-Share System Mato]. Paper presented at the Temu Masyarakat Akuntansi Multiparadigma Nasioanal 4 (Teman4), Jakarta.

Hanif, Unti Ludigdo, Aulia Fuad Rahman, \& Baridwan, Z. (2013a, 25-28 September). Refleksi Nilai-Nilai Pancasila Dalam Akuntansi Bagi Hasil [Reflection on Pancasila Values in Profit Share Accounting] Paper presented at the Seminar Nasional Akuntansi (SNA), Manado, Indonesia.

Hanif, Unti Ludigdo, Aulia Fuad Rahman, \& Baridwan, Z. (2013b, 25-28 September ). Memaknai Corporate Governance Berbasis Kearifan Lokal [Understanding Corporate Governance Based on Local Wisdom]. Paper presented at the Seminar Nasional Akuntansi (SNA), Manado, Indonesia.

Hanif, Unti Ludigdo, Aulia Fuad Rahman, \& Zaki Baridwan. (2015). Akuntansi Bagi-Hasil Sistem Mato: Etnografi Bisnis Restoran Padang [Accounting for Profit-Sharing Mato System: Business Ethnography Padang Restaurant]. Jakarta: Mitra Wacana Media.

Kamayanti, A. (2016). Metode Penelitian Kualitatif Akuntansi. Jl. Warung Buncit Raya 405 Jakarta Selatan.

Kasali, R. (2016). Blue Bird-Taksi Express Harus Masuk ke Aplikasi [Express Taxi Must Enter App] "Online", Kompas Newspaper.

Naim, M., Wall, P. Asril, Z. \& Rasyid, F. (1987). Jurus Manajemen Indonesia: Sistem Pengelolaan Restoran Minang Sebuah Prototipe Sistem Ekonomi Pancasila [Management Jurus Indonesia: Minang Restaurant Management System. A Prototype of Pancasila Economic System]. Jakarta: Yayasan Obor Indonesia.

Prasetyantoko, A. (2016). Paradoks Ekonomi Berbagi [Paradox of Sharing Economy], Kompas Newspaper.

Priyono, H. (2016). Kritik Untuk Ekonomi Berbagi [Criticisms for a Sharing Economy], Kompas Newspaper.

Triyuwono, I. (2012). Akuntansi Syariah: Perspektif, Metodologi, dan Teori Akuntansi syariah [Sharia Accounting: Perspectives, Methodology, and Theory of Sharia Accounting]. Jakarta: PT. Rajagrafindo Persada. 